\title{
HAK ANGKET SEBAGAI FUNGSI PENGAWASAN DEWAN PERWAKILAN RAKYAT
}

Kajian Putusan Mahkamah Konstitusi Nomor 36/PUU-XV/2017

\section{INQUIRY RIGHT AS A SUPERVISORY FUNCTION OF THE HOUSE OF REPRESENTATIVES}

\author{
An Analysis of Constitutional Court Decision Number 36/PUU-XV/2017
}

\author{
Mei Susanto \\ Departemen Hukum Tata Negara Fakultas Hukum Universitas Padjadjaran \\ Jl. Dipati Ukur No. 35, Bandung 40135 \\ E-mail:m.susanto@unpad.ac.id
}

Naskah diterima: 16 Juli 2018; revisi: 24 Oktober 2018; disetujui: 6 Desember 2018

http://dx.doi.org/10.29123/jy.v11i3.326

\begin{abstract}
ABSTRAK
Putusan Nomor 36/PUU-XV/2017 menguji konstitusionalitas objek hak angket Dewan Perwakilan Rakyat terhadap Komisi Pemberantasan Korupsi. Permasalahan dalam penelitian ini adalah bagaimana hak angket menurut putusan a quo dikonstruksikan sebagai fungsi pengawasan Dewan Perwakilan Rakyat, dan bagaimana implikasinya terhadap objek hak angket Dewan Perwakilan Rakyat dalam ketatanegaraan Indonesia. Penelitian ini merupakan penelitian doktrinal, dengan menggunakan bahan hukum primer dan sekunder yang relevan dengan objek penelitian. Penelitian menyimpulkan, pertama, putusan a quo telah mengkonstruksikan hak angket tidak hanya dalam kerangka pengawasan yang hasilnya berujung pada penjatuhan sanksi bagi pejabat publik yang melanggar undang-undang, melainkan juga pengawasan pelaksanaan undang-undang yang hasilnya berupa perubahan kebijakan dalam rangka perubahan undangundang (legislasi) maupun kebijakan lainnya. Putusan a quo juga mengkonstruksi Komisi Pemberantasan Korupsi sebagai lembaga negara penunjang dalam ranah eksekutif yang independen, namun tetap dapat
\end{abstract}

menjadi objek hak angket Dewan Perwakilan Rakyat. Kedua, putusan a quo secara positif berimplikasi dapat digunakannya hak angket dalam rangka perubahan undang-undang sehingga dapat meningkatkan efektivitas legislasi, namun secara negatif berimplikasi dapat digunakannya hak angket secara eksesif terhadap kelembagaan yang dijamin independensinya dan terhadap objek yang seharusnya tidak dapat diselidiki karena dilindungi hukum, misalnya hak privasi dan penegakan hukum. Implikasi eksesif tersebut disebabkan putusan a quo tidak memberikan batasan terhadap penggunaan hak angket Dewan Perwakilan Rakyat.

Kata kunci: Dewan Perwakilan Rakyat, hak angket, pengawasan.

\section{ABSTRACT}

Constitutional Court Decision Number 36/PUUXV/2017 examines the constitutionality of the inquiry right's object of the House of Representatives over the Corruption Eradication Commission. The problem in this study is how inquiry right is constructed as a supervisory function of the House based on decision a quo, and what the implications are for the object of the 
House 's inquiry right in Indonesian state administration. This doctrinal research uses primary and secondary legal materials relevant to the object of research. The study concludes that (1) the decision a quo constructs the right of inquiry not only within the framework of supervision which results in the imposition of sanctions on public officials violating the law, but also supervision of the implementation of laws resulting in policy changes in the terms of amendment of laws and other policies; (2) a quo ruling can positively imply the right of inquiry to be used in the context of amending the law to improve the effectiveness of legislation, but it can negatively have implications for inquiry rights that are excessively used against independency-guaranteed institutions and for objects that cannot be investigated because they are protected by the law, such as privacy rights and law enforcement. The excessive implication of this decision will happen as it does not define the limits on the House's inquiry right to invesigate into a specific issue.

Keywords: House of Representatives, inquiry right, supervision.

\section{PENDAHULUAN}

\section{A. Latar Belakang}

Putusan Nomor 36/PUU-XV/2017 mengenai uji konstitusionalitas hak angket Dewan Perwakilan Rakyat terhadap Komisi Pemberantasan Korupsi, dapat dikatakan sebagai putusan yang memberikan kejelasan mengenai objek hak angket Dewan Perwakilan Rakyat yang selama ini diperdebatkan, khususnya status Komisi Pemberantasan Korupsi sebagai lembaga negara independen yang dianggap tidak dapat menjadi objek hak angket. Putusan tersebut tetap dianggap kontroversial, karena telah memposisikan Komisi Pemberantasan Korupsi sebagai bagian dari organ eksekutif.

Empat Putusan Mahkamah Konstitusi sebelumnya, yaitu Putusan Nomor 012-016-019/ PUU-IV/2006, Putusan Nomor 19/PUU-V/2007, Putusan Nomor 37-39/PUU-VIII/2010, dan Putusan Nomor 5/PUU-IX/2011, pada intinya menyatakan Komisi Pemberantasan Korupsi adalah organ negara independen yang tidak termasuk ke dalam organ eksekutif, legislatif maupun yudikatif. Karenanya tidak heran, jika dalam Putusan Nomor 36/PUU-XV/2017 terdapat empat orang hakim konstitusi yang menyatakan pendapat berbeda (dissenting opinion) dengan menyatakan bahwa Komisi Pemberantasan Korupsi tidak dapat menjadi objek dari hak angket Dewan Perwakilan Rakyat karena merupakan lembaga independen.

Kontroversi tersebut tentu menjadi menarik untuk dikaji, khususnya berkaitan objek dari hak angket sebagai bagian dari fungsi pengawasan Dewan Perwakilan Rakyat. Timbul berbagai persoalan, misalnya apakah sebuah organ yang disebut independen masih dapat dijadikan objek hak angket Dewan Perwakilan Rakyat. Bila dapat menjadi objek hak angket, apakah hal tersebut dapat dikatakan akan mengganggu atau bahkan merusak status independensi dari organ tersebut. Sebaliknya muncul persoalan lainnya, apakah jika sebuah organ independen tidak dapat menjadi objek hak angket, lalu bagaimana model pengawasan yang dapat dilakukan oleh Dewan Perwakilan Rakyat sebagai organ negara yang secara konstitusional melekat fungsi pengawasan penyelenggaraan negara.

Hal ini berkaitan dengan sisi pertanggungjawaban dan akuntabilitas sebuah lembaga negara. Bukankah pada negara hukum yang demokratis, tidak ada jabatan 
atau pemangku jabatan (maksudnya adalah lembaga negara atau pejabat negara) yang tidak dipertanggungjawabkan (Manan, 2003: 66-68).

Selain persoalan objek hak angket tersebut, hal lain yang menarik adalah alasan yang dikemukakan Dewan Perwakilan Rakyat, misalnya karena Komisi Pemberantasan Korupsi menolak untuk menyerahkan rekaman pemeriksaan MSH dalam Rapat Dengar Pendapat Komisi III, ketidakharmonisan pimpinan Komisi Pemberantasan Korupsi, ataupun penggunaan keuangan yang dianggap tidak sesuai berdasarkan laporan Badan Pemeriksaan Keuangan.

Alasan-alasan tersebut juga menjadi menarik untuk dikaji, mengingat Pasal 97 ayat (3) Undang-Undang Nomor 17 Tahun 2014 menyebutkan hak angket adalah "hak Dewan Perwakilan Rakyat untuk melakukan penyelidikan terhadap pelaksanaan undang-undang dan/atau kebijakan pemerintah yang berkaitan dengan hal penting, strategis, dan berdampak luas pada kehidupan bermasyarakat, berbangsa, dan bernegara yang diduga bertentangan dengan peraturan perundang-undangan." Timbul pertanyaan, apakah pertimbangan atau alasan yang dikemukakan oleh Dewan Perwakilan Rakyat dalam menggunakan hak angket terhadap Komisi Pemberantasan Korupsi telah memenuhi syarat yang diatur dalam Pasal 97 ayat (3) Undang-Undang Nomor 17 Tahun 2014 tersebut?

Berdasarkan latar belakang tersebut, maka tulisan ini hendak mengkaji persoalan hak angket Dewan Perwakilan Rakyat dari Putusan Nomor 36/PUU-XV/2017. Adapun sudut pandang yang diambil, ditekankan pada hak angket sebagai fungsi pengawasan Dewan Perwakilan Rakyat. Titik tekan tersebut penting, mengingat hak angket sering kali dikonstruksikan sebagai bagian dari fungsi pengawasan badan perwakilan atau parlemen, bahkan dalam sistem pemerintahan parlementer dapat berujung pada mosi tidak percaya. Dalam Undang-Undang Nomor 17 Tahun 2014, terkait dengan hak angket disatukan dalam satu bagian pelaksanaan hak Dewan Perwakilan Rakyat bersama dengan hak interpelasi dan hak menyatakan pendapat.

Apabila dibaca secara sistematis, antar hak interpelasi, hak angket, dan hak menyatakan pendapat, dibuat saling berkaitan. Misalnya dalam Pasal 197 yang membicarakan tentang hak interpelasi, disebutkan dalam ayat (3), yaitu: “dalam hal Dewan Perwakilan Rakyat menolak penjelasan Presiden atau pimpinan lembaga sebagaimana dimaksud pada ayat (1), Dewan Perwakilan Rakyat dapat menggunakan hak Dewan Perwakilan Rakyat lainnya" (garis miring penulis). Hak Dewan Perwakilan Rakyat lainnya yang dimaksud dapat berupa hak angket atau hak menyatakan pendapat.

Pasal 208 yang membicarakan hak angket, disebutkan dalam ayat (1), yaitu: "apabila rapat paripurna Dewan Perwakilan Rakyat sebagaimana dimaksud dalam Pasal 206 ayat (2) memutuskan bahwa pelaksanaan suatu undangundang dan/atau kebijakan pemerintah yang berkaitan dengan hal penting, strategis, dan berdampak luas pada kehidupan bermasyarakat, berbangsa, dan bernegara bertentangan dengan ketentuan peraturan perundang-undangan, Dewan Perwakilan Rakyat dapat menggunakan hak menyatakan pendapat" (garis miring penulis). Pasal 210 ayat (2) disebutkan bahwa terkait dengan mekanisme pengusulan hak menyatakan pendapat disertai dengan dokumen yang memuat paling sedikit "(b) materi pelaksanaan hak interpelasi atau hak angket...". 
Membaca bagian pelaksanaan hak Dewan Perwakilan Rakyat secara satu kesatuan, maka hak angket adalah satu paket dengan hak interpelasi dan hak menyatakan pendapat sebagai turunan dari fungsi pengawasan. Timbul pertanyaan, apakah penyatuan ini tepat? Apakah hak angket hanya sebagai fungsi pengawasan yang dapat berujung pada hak menyatakan pendapat saja, atau hak angket dapat juga dipergunakan dalam rangka menjalankan fungsi pengawasan lainnya? Hal inilah yang hendak dianalisis dalam tulisan ini, sebagai upaya memberikan makna yang tepat terhadap hak angket sebagai fungsi pengawasan Dewan Perwakilan Rakyat tersebut.

\section{B. Rumusan Masalah}

Berdasarkan uraian di atas, maka rumusan masalah dalam tulisan ini adalah:

1. Bagaimana hak angket menurut Putusan Nomor 36/PUU-XV/2017 dikonstruksikan sebagai fungsi pengawasan Dewan Perwakilan Rakyat?

2. Bagaimana implikasi Putusan Nomor 36/PUU-XV/2017 terhadap objek hak angket Dewan Perwakilan Rakyat dalam ketetanegaraan Indonesia?

\section{Tujuan dan Kegunaan}

Tulisan ini bertujuan untuk mengkaji dan menganalisis Putusan Nomor 36/PUU-XV/2017 yang memberikan dasar konstitusionalitas hak angket sebagai fungsi pengawasan Dewan Perwakilan Rakyat serta objek hak angketnya dalam ketatanegaraan Indonesia.

Tulisan ini diharapkan memiliki kegunaan, yaitu: (1) sumbangsih pemikiran berkaitan dengan persoalan hak angket sebagai fungsi pengawasan Dewan Perwakilan Rakyat dalam ketanegaraan Indonesia, khususnya untuk memperjelas hak angket sebagai penyelidikan dalam arti investigasi, bukan hak angket sebagai penyelidikan dalam rangka penegakan hukum (pro justicia); dan (2) menganalisis implikasi Putusan Nomor 36/PUU-XV/2017 terhadap objek hak angket Dewan Perwakilan Rakyat dalam ketatanegaraan Indonesia.

\section{Tinjauan Pustaka}

Tulisan ini akan menggunakan teori fungsi pengawasan badan perwakilan rakyat dalam pemerintahan yang demokratis yang kemudian melahirkan konsep hak angket atau investigasi yang dimiliki badan perwakilan. Teori fungsi pengawasan badan perwakilan sejatinya ada seiring dengan lahirnya paham kedaulatan rakyat yang telah dikenal sejak era Yunani Kuno yang dikenal dengan ekklesia sebagai majelis perwakilan yang melakukan persidangan dalam rangka mengecek implementasi hukum yang telah dibuat (Srem-Sai, 2014: 1). Sekitar abad ke-18, Montesquieu melahirkan ide pemisahan kekuasaan menjadi eksekutif, legislatif, dan yudikatif, dengan mengatakan:

A"When the legislative and executive powers are united in the same person, or in the same body of magistrates, there can be no liberty..." (Montesquieu, 2001: 173174).

Idealisasi konsep pemisahan kekuasaan yang digagas Montesquieu tersebut dalam praktik sulit dilakukan, bahkan melahirkan kesewenangwenangan dari tiap cabang kekuasaan tersebut, karena itu lahirlah teori modifikasi seperti teori pembagian kekuasaan dan teori saling mengawasi (checks and balances) (Manan, 2006: 8; Asshiddiqie, 2006: 15; Susanto, 2013: 84- 
85). Khusus untuk kekuasaan legislatif, ia tidak hanya dilekatkan fungsi pembentukan undangundang, melainkan juga fungsi pengawasan guna memastikan jalannya undang-undang yang dibentuknya. Hal ini sejalan dengan pendapat Mill pada abad ke-19 yang mengatakan:

"the proper office of a representative assembly is to watch and control the government: to throw the light of publicity on its acts: to comple a full exposition and justification of all of them which anyone considers questionable: to censure them if found condemnable, and if the men who compose the government abuse their trust, or fulfil it in a manner which conflicts with the deliberate sense of the nation, to expel them from office..." (Mill, 1861: 104).

Fungsi badan perwakilan tidak berhenti pada pembentukan undang-undang saja, melainkan juga memastikan bagaimana implementasi undangundang sesuai dengan maksud pembentukannya. Sejalan dengan itu The National Democratic Institute's menyebutkan “... highlights a vital aspect of the legislature's oversight responsibility - the need for the legislature to ensure that its law are implemented in accordance with its tension" (dalam Srem-Sai, 2014: 2).

Mengikuti konsep Montesquieu dan Mill tersebut, model pengawasan badan perwakilan saat ini muncul dalam bentuk yang bervariasi. Kaiser dengan mendasarkan pada model sistem presidensial Amerika memberikan contoh variasi bentuk pengawasan tersebut dalam bentuk "hearing, formal consultation, senate advice and consent, house impeachment and senate trial, informal meetings, legislator ombudsman, studies and reviews, investigation" (Kaiser, 1988 : 76-77).

Dari 88 negara yang badan perwakilan/ parlemennya dibandingkan dalam fungsi pengawasan, Yamamoto menyebut tujuan dari fungsi pengawasan parlemen adalah:

1. to detect and prevent abuse, arbitrary behaviour, or illegal and unconstitutional conduct on the part of the government and public agencies. At the core of this function is the protection of the rights and liberties of citizens;

2. to hold the government to account in respect of how the taxpayers' money is used. It detects waste within the machinery of government and public agencies. Thus it can improve the efficiency, economy and effectiveness of government operations;

3. to ensure that policies announced by the government and authorized by parliament are actually delivered. This function includes monitoring the achievement of goals set by legislation and the government's own programmes; and

4. to improve the transparency of government operations and enhance public trust in the government, which is itself a condition of effective policy delivery (Yamamoto, 2007: 9-10).

Berangkat dari tujuan tersebut, menurut Yamamoto sarana yang dapat dipergunakan dalam menjalan fungsi pengawasan dapat berupa: (1) parlemen dapat bertanya kepada pemerintah untuk memperoleh informasi; (2) parlemen dapat bertanya kepada pemerintah untuk memberikan klarifikasi terhadap kebijakan publik yang diambil; (3) parlemen dapat memperoleh informasi dari sumber di luar pemerintah; dan (4) parlemen dapat menyatakan pandangannya kepada pemerintah dan publik (Yamamoto, 2007: 10).

Berdasarkan perbandingan yang dilakukan Yamamoto tersebut, salah satu bentuk dari pengawasan adalah penyelidikan parlemen. 
Penyelidikan parlemen tersebut umumnya memiliki kekuasaan yang bersifat khusus dan hanya dapat digunakan dalam kaitannya dengan objek penyelidikan serta waktu yang terbatas (Yamamoto, 2007: 39-40).

Dari uraian yang telah dikemukakan, maka penyelidikan parlemen atau investigasi badan perwakilan atau hak angket merupakan suatu bentuk dari fungsi pengawasan yang melekat pada badan perwakilan rakyat dalam kerangka memastikan undang-undang yang telah dibuatnya dijalankan secara tepat dan benar sesuai dengan tujuan dari pembentukan undangundang tersebut.

\section{METODE}

Penelitian ini merupakan penelitian hukum (legal research) untuk menemukan aturan hukum, prinsip-prinsip hukum, maupun doktrindoktrin hukum guna menjawab isu-isu hukum yang dihadapi (Istanto, 2007: 29; Marzuki, 2005: 35). Adapun isu hukum yang dihadapi adalah persoalan hak angket sebagai fungsi pengawasan Dewan Perwakilan Rakyat yang terdapat dalam Putusan Nomor 36/PUU-XV/2017.

Jenis penelitian yang digunakan dalam tulisan ini adalah penelitian pustaka (library research), yaitu penelitian yang menggunakan dokumen tertulis sebagai data, dan sumber data yang digunakan dalam penelitian ini mencakup bahan hukum primer dan bahan hukum sekunder. Penelitian ini menggunakan pendekatan doktrinal yang condong bersifat kualitatif berdasarkan data sekunder (Supranto, 2003: 2).

Penulis menggunakan pendekatan perundang-undangan (statute approach), pendekatan konseptual (conceptual approach), dan pendekatan perbandingan (comparative approach). Pendekatan perundang-undangan (statute research) digunakan untuk meneliti, mendalami, dan menelaah berbagai peraturan perundang-undangan yang menjadi tema sentral dalam penelitian yaitu mengenai hak angket Dewan Perwakilan Rakyat.

Pendekatan konseptual (conceptual approach) digunakan untuk mendalami konsep hak angket yang diletakkan sebagai pranata fungsi pengawasan Dewan Perwakilan Rakyat, sehingga apakah hasil rekomendasi angket hanya berujung pada proses hak menyatakan pendapat, atau dapat juga berkaitan dengan fungsi Dewan Perwakilan Rakyat lainnya. Pendekatan perbandingan (comparative approach) digunakan untuk melihat praktik penggunaan hak angket atau hak melakukan penyelidikan oleh parlemen atau badan perwakilan.

\section{HASIL DAN PEMBAHASAN}

A. Konstruksi Hak Angket Sebagai Fungsi Pengawasan Dewan Perwakilan Rakyat dalam Putusan Nomor 36/PUU-XV/2017

Selain Putusan Nomor 36/PUU-XV/2017, sebenarnya terdapat dua putusan Mahkamah Konstitusi lainnya, yaitu Putusan Nomor 37/ PUU-XV/2017 dan 40/PUU-XV/2017 yang juga menguji konstitusionalitas penggunaan hak angket Dewan Perwakilan Rakyat terhadap Komisi Pemberantasan Korupsi, yang pihak pemohonnya berbeda-beda. Majelis hakim dalam Putusan Nomor 37/PUU-XV/2017 menyatakan tidak dapat menerima permohonan pengujian karena pemohon tidak pernah hadir di sidang pleno pemeriksaan perkara. Sementara dalam Putusan Nomor 40/PUU-XV/2017 menyatakan pertimbangan hakim konstitusi pada Putusan 
Nomor 36/PUU-XV/2017 berlaku mutatis mutandis, karena itu, dua putusan tersebut tidak dipergunakan secara langsung dalam analisis dalam artikel ini.

Putusan Nomor 36/PUU-XV/2017 sendiri tidak diputus secara bulat oleh sembilan hakim konstitusi. Berdasarkan salinan putusan resmi yang diperoleh, komposisi hakim konstitusi adalah 5:4 (lima banding empat), artinya putusan terkait dengan hak angket tersebut tidak diputuskan secara bulat, yang menunjukkan adanya perbedaan sudut pandang dari para hakim yang memutus perkara.

Apabila dilihat, pertimbangan hakim konstitusimayoritasyangkemudianmengantarkan pada amar putusan, maupun hakim konstitusi minoritas yang dissenting opinion, memiliki konstruksi yang sama dalam menjelaskan hak angket sebagai fungsi pengawasan Dewan Perwakilan Rakyat, yang dapat dilihat dari aspek istilah, sejarah, perbandingan, dan tujuan penggunaan hak angket (lihat tabel 1).

Tabel 1. Perbandingan Pertimbangan Hakim Konstitusi Terkait Konsep Hak Angket

\begin{tabular}{|c|c|c|}
\hline Isu & $\begin{array}{c}\text { Pertimbangan Hakim Konstitusi Mayoritas } \\
\text { yang Menjadi Dasar Putusan }\end{array}$ & $\begin{array}{c}\text { Pertimbangan Hakim Konstitusi Minoritas } \\
\text { yang Dissenting Opinion }\end{array}$ \\
\hline Istilah & $\begin{array}{l}\text { "angket" berasal dari bahasa Perancis "enquete" } \\
\text { yang berarti "penyelidikan." }\end{array}$ & $\begin{array}{l}\text { Hak parlemen untuk melakukan penyelidikan } \\
\text { disebut parliamentary investigation. }\end{array}$ \\
\hline $\begin{array}{l}\text { Sejarah } \\
\text { hak angket } \\
\text { pertama kali } \\
\text { dipergunakan }\end{array}$ & $\begin{array}{l}\text { Parlemen Inggris pada tahun } 1367 \text { merupakan } \\
\text { institusi pertama yang memulai penggunaan hak } \\
\text { angket saat digunakannya right to investigate } \\
\text { and chastise the abuse of administration, dengan } \\
\text { tujuan menjatuhkan sanksi dalam pemecatan } \\
\text { terhadap pejabat pemerintah. }\end{array}$ & $\begin{array}{l}\text { Hak angket merupakan bagian pelaksanaan } \\
\text { pengawasan Parlemen terhadap pemerintah } \\
\text { (eksekutif), mula-mula berkembang di } \\
\text { Inggris, khususnya pasca Glorius Revolution } \\
\text { (1688) yang ditandai oleh runtuhnya } \\
\text { kekuasaan monarki absolut di Inggris, } \\
\text { sehingga secara evolutif lahir praktik } \\
\text { pemerintahan yang bertanggung jawab } \\
\text { (responsible government) sebagai dasar } \\
\text { sistem pemerintahan perlementer Inggris, } \\
\text { atau yang dikenal dengan mosi tidak percaya. }\end{array}$ \\
\hline $\begin{array}{l}\text { Perbandingan } \\
\text { penggunaan } \\
\text { hak angket } \\
\text { berdasarkan } \\
\text { sistem } \\
\text { pemerintahan }\end{array}$ & $\begin{array}{l}\text { Walaupun pertama dipergunakan di Inggris yang } \\
\text { menganut sistem pemerintahan parlementer, } \\
\text { namun praktik ketatanegaraan di Amerika Serikat } \\
\text { yang menganut sistem pemerintahan presidensil } \\
\text { juga mengenal hak angket (pengawasan dalam } \\
\text { bentuk investigasi) sebagai implied power dari } \\
\text { kekuasaan Kongres, dengan mendasarkan pada } \\
\text { pendapat pengadilan dalam kasus Watkins vs. } \\
\text { United States yang mengatakan "the power of the } \\
\text { Congress to conduct investigation is inherent in } \\
\text { the legislative process." }\end{array}$ & $\begin{array}{l}\text { Sistem pemerintahan presidensil yang } \\
\text { diperkenalkan di Amerika Serikat tidak } \\
\text { mengenal responsible government, walau } \\
\text { demikian Kongres Amerika tetap memiliki } \\
\text { hak melakukan investigasi dengan nama } \\
\text { congresional oversight terhadap eksekutif } \\
\text { sebagai kekuasaan yang implisit yang } \\
\text { mencakup aspek yang luas, yaitu meninjau, } \\
\text { memonitor, dan mensupervisi implementasi } \\
\text { kebijakan publik. }\end{array}$ \\
\hline $\begin{array}{l}\text { Kesimpulan } \\
\text { mengenai } \\
\text { tujuan } \\
\text { penggunaan } \\
\text { hak angket }\end{array}$ & $\begin{array}{l}\text { Hasil penyelidikan hak angket tidak harus selalu } \\
\text { berujung pada penggunaan hak menyatakan } \\
\text { pendapat, apalagi semata-mata berupa } \\
\text { rekomendasi/usulan penggantian terhadap pejabat } \\
\text { tertentu yang melanggar undang-undang. Hak } \\
\text { angket sebagai instrumen pengawasan Dewan } \\
\text { Perwakilan Rakyat, dapat dipergunakan untuk } \\
\text { menemukan dan merumuskan kebijakan dalam } \\
\text { rangka perbaikan undang-undang, standard } \\
\text { operating procedure maupun kebijakan lainnya. }\end{array}$ & $\begin{array}{l}\text { Hasil penyelidikan hak angkte baik } \\
\text { dalam sistem parlementer dan sistem } \\
\text { presidensil sama-sama untuk pengawasan } \\
\text { terhadap eksekutif. Bedanya, dalam sistem } \\
\text { parlementer, parliamentary investigation } \\
\text { dapat berujung pada jatuhnya pemerintahan, } \\
\text { sementara dalam sistem presidensil, } \\
\text { congressional oversight tidak dapat berujung } \\
\text { pada jatuhnya pemerintahan. }\end{array}$ \\
\hline
\end{tabular}


Pertama, dari perspektif istilah, hakim konstitusi mayoritas menyebut mengatakan "menimbang bahwa dalam perspektif semantik dan historis, kata "angket" berasal dari bahasa Perancis "enquete" yang berarti penyelidikan," sementara hakim konstitusi yang dissenting opinion hanya menyebut hak parlemen untuk melakukan penyelidikan dalam bahasa Inggris disebut parliamentary investigation. Dari perspektif istilah tersebut, pertimbangan hakim konstitusi hanya sampai pada istilah dan arti saja tanpa kemudian memperdalamnya, padahal kata "penyelidikan" dalam tata hukum Indonesia lebih sering dipergunakan dalam rangka hukum acara pidana.

Hal ini seharusnya diperjelas agar tidak dipersamakan antara "penyelidikan" dalam hukum acara pidana dengan "penyelidikan" dalam arti hak angket Dewan Perwakilan Rakyat. Sebagai perbandingan, istilah angket atau enquete sendiri masih dipertahankan sebagai salah satu kewenangan Parlemen Perancis yang dapat dilihat dalam Pasal 51 ayat (2) Konstitusi Perancis, yaitu: "pour l'exercice des missions de contrôle et d'évaluation définies au premier alinéa de l'article 24, des commissions d'enquête peuvent être créées au sein de chaque assemblée pour recueillir, dans les conditions prévues par la loi, des éléments d'information" (cetak tebal penulis).

Dalam laman constituteproject.org yang mengkompilasi konstitusi-konstitusi berbagai negara, istilah commissions d'enquete dalam Pasal 51 ayat (2) Konstitusi Perancis tersebut diartikan dalam bahasa Inggris sebagai committees of inquiry. Sementara itu dalam Konstitusi Belanda sebagaimana ditampilkan website resmi Pemerintah Belanda (Netherlands Government, 2012), Pasal 70 juga menyebut istilah angket dengan istilah enquete/inquiry, yaitu: "The two Houses shall jointly and separately have the right of inquiry (enquête) to be regulated by Act of Parliament." Di Amerika Serikat, juga dikenal adanya congressional inquiry sebagai salah satu kekuasaan investigasi Kongres Amerika (Senat Amerika, 2018).

Artikel yang ditulis di berbagai jurnal, istilah inquiry dan investigation saling dipergunakan untuk menjelaskan salah satu kekuasaan lembaga perwakilan untuk melakukan penyelidikan. Misalnya artikel yang ditulis oleh Ehrmann (1943: 117) dengan judul The Duty of Disclosure in Parliamentary Investigation: A Comparative Study dalam The University of Chicago Law Review. Ada juga artikel yang ditulis Harpine (1956: 64) dengan judul Congressional Investigating Power, Judicial Interpretations of the Scope of Inquiry.

Dengan demikian, istilah yang sepadan untuk menunjuk kata "penyelidikan" dalam arti "hak angket" yang dimiliki oleh badan perwakilan/ parlemen adalah enquete, inquiry, dan juga investigation. Hal tersebut berbeda dengan istilah "penyelidikan" dalam rangka penegakan hukum pidana (pro justicia) yang padanan dalam bahasa Belanda opsporing. Pembedaan tersebut perlu dilakukan agar tidak terjadi kesalahpahaman dalam memaknai "penyelidikan" dalam hak angket yang tidak dilakukan dalam rangka penegakan hukum pidana.

Hal tersebut sejalan dengan salah satu definisi hak angket dalam Webster (2018), bahwa "inquiry is examination into facts or principles, research or a request for information or a systematic investigation often of a matter of public interest." Dengan demikian, penyelidikan atau angket adalah upaya untuk menguji fakta- 
fakta atau prinsip-prinsip, penelitian atau sebuah permintaan atas informasi atau sebuah investigasi yang sistematik terkait dengan kepentingan publik, namun tidak langsung berkaitan dengan penegakan hukum.

Pencampur-adukan istilah penyelidikan di Indonesia, mungkin dikarenakan praktik yang terjadi, hak angket ditujukan untuk menemukan bukti awal mengenai dugaan telah terjadi suatu pelanggaran hukum pidana sebagaimana dalam hak angket Dewan Perwakilan Rakyat yang dipergunakan pada kasus Bulloggate, Bantuan Likuiditas Bank Indonesia (BLBI), Semanggi I dan II, dan kasus Bank Century (Naswar, 2012: $3)$.

Kedua, dari perspektif sejarah. Baik itu hakim konstitusi yang mayoritas maupun yang dissenting opinion, mengungkapkan bahwa sejarah pertama kali penggunaan hak angket adalah oleh Parlemen Inggris. Hanya saja berbeda pada waktu pertama dipergunakan hak angket dan titik tekannya. Hakim konstitusi mayoritas mengungkap bahwa penggunaan hak angket oleh Parlemen Inggris dimulai pada tahun 1376 saat dipergunakannya the right to investigate and chastise the abuses of administration.

Hakim konstitusi yang dissenting opinion menyebut penggunaan hak angket bermula pada pasca Glorius Revolution (1688) dengan runtuhnya kekuasaan monarki absolut di Inggris di bawah Raja James II. Dengan demikian, dua pendapat kelompok hakim konstitusi sama-sama menyebut Parlemen Inggris-lah yang pertama kali mempergunakan hak angket, namun berbeda dari aspek waktu awal mula penggunaan hak angket saja.

Hal yang menarik untuk dicermati dari aspek sejarah penggunaan hak angket di Inggris tersebut adalah soal titik tekan, di mana hakim konstitusi yang melakukan dissenting opinion menekankan penggunaan hak angket sebagai bentuk pertanggungjawaban pemerintah, bahkan dapat berujung pada "mosi tidak percaya" (motion of no confidence). Penekanan tersebut menjadi penting sebagai salah satu watak atau ciri dari penggunaan hak angket di Inggris.

Ketiga, dari perspektif perbandingan. Setelah menjelaskan sejarah pertama kali dipergunakannya hak angket di Inggris sebagai bagian dari sistem parlementer, baik hakim konstitusi yang mayoritas maupun yang melakukan dissenting opinion selanjutnya melakukan perbandingan penggunaan hak angket di Amerika Serikat yang menerapkan sistem presidensial. Adapun dalam pertimbangannya, hakim konstitusi yang mayoritas mengatakan:

"Walaupun pada awalnya berasal, dikenal, dan dipraktikkan dalam sistem pemerintahan parlementer Inggris, dalam perkembangannnya pranata pengawasan secara substansial sebagaimana hak angket juga lazim digunakan di negara-negara yang menganut sistem pemerintahan presidensial. Mengacu pada praktik ketatanegaraan di Amerika Serikat, fungsi pengawasan tidak dicantumkan secara eksplisit di dalam Konstitusi Amerika Serikat. Akan tetapi, fungsi tersebut dijalankan Kongres sebagai implied power dari fungsi legislasi dan fungsi anggaran. Pada praktiknya, dalam fungsi pengawasan yang dilakukan Kongres, dijumpai bentuk bentuk penyelidikan (investigative) yang secara prinsip memiliki tujuan yang sama dengan hak angket.

Lebih jelas lagi, dalam perkara Watkins vs. United States, pengadilan berpendapat, "the power of the Congress to conduct investigation is inherent in the legislative process. The power is broad. It compasses in inquiries concerning administration of existing laws as well as proposed or possibly needed by statutes." Artinya, pengadilan berpendapat bahwa Kongres 
memiliki kewenangan melakukan penyelidikan dan mempublikasikan kasus korupsi, maladministrasi, atau inefisiensi pada badan pemerintahan. Praktik demikian menunjukkan dengan jelas, Kongres Amerika Serikat memiliki sekaligus kewenangan dan hak interpelasi (bertanya), angket (penyelidikan), serta menyatakan pendapat. Tambah jelas lagi, praktik pengawasan investigatif oleh Kongres Amerika Serikat dijumpai dalam kasus Watergate yang menyebabkan Presiden Richard Nixon mengundurkan diri sebelum di-impeach. Praktik ketatanegaraan di Amerika Serikat tersebut cukup untuk menunjukkan bahwa hak angket sebagai instrumen pengawasan relevan diberlakukan dalam sistem presidensial."

Sementara itu, hakim konstitusi yang menyatakan dissenting opinion mengatakan:

“... hak yang dalam sistem parlementer dinamakan parliamentary investigation itu tetap diadopsi dalam sistem presidensial, yang di Amerika Serikat dinamakan congressional oversight terhadap cabang kekuasaan eksekutif (pemerintah, termasuk badan-badan federal) sebagai bagian dari investigation power yang dimiliki oleh Kongres kendatipun hal itu tidak dinyatakan secara eksplisit dalam Konstitusi Amerika Serikat melainkan hanya implisit. Namun demikan, hak ini (congressional oversight) mencakup aspek yang sangat luas, yaitu meninjau, memonitor, dan mensupervisi implementasi kebijakan pulik."

Penggunaan perbandinganhak angketdalam ketatanegaraan Inggris yang merepresentasikan sistem parlementer, maupun penggunaan hak angket dalam ketatanegaraan Amerika Serikat yang merepresentasikan sistem presidensial oleh hakim konstitusi tersebut dapat dikatakan cukup tepat, mengingat dalam konteks Indonesia, sering kali hak angket dianggap pranata yang hanya dimiliki oleh negara yang menganut sistem pemerintahan parlementer. Misalnya Indrayana (2017) yang mengatakan "angket, dalam sejarahnya, adalah hak parlemen dalam sistem parlementer. Ini merupakan salah satu karakter parlementer dalam sistem presidensial di Indonesia."

Apabila merujuk pada Putusan Nomor 8/ PUU-VIII/2010 yang mengabulkan permohonan pembatalan Undang-Undang Nomor 6 Tahun 1954 tentang Penetapan Hak Angket Dewan Perwakilan Rakyat karena alasan dasar hukum pembentukan undang-undang tersebut adalah Undang-Undang Dasar Sementara 1950 yang menerapkan sistem parlementer, sementara UUD NRI 1945 yang saat ini berlaku, khususnya pasca perubahan menganut sistem presidensial, sehingga pengaturan mengenai penggunaan hak angket tersebut harus disesuaikan.

Adanya pertimbangan hakim konstitusi tersebut, maka perdebatan mengenai tepat tidaknzya hak angket disematkan pada badan perwakilan rakyat (dalam hal ini Dewan Perwakilan Rakyat) dalam ketatanegaraan Indonesia dapat diakhiri. Hakikatnya setiap badan perwakilan baik dalam sistem presidensial maupun sistem parlementer selalu disematkan kekuasaan pengawasan, salah satunya adalah pengawasan dalam bentuk penyelidikan.

Sebagai perbandingan lebih dalam, di Amerika Serikat kekuasaan penyelidikan yang dimiliki oleh badan perwakilan (baca Kongres), merupakan kekuasaan konstitusional yang implied power (Senat Amerika, 2018). Madison dalam Federalis Paper 51 menyebut kekuasaan penyelidikan yang dimiliki Kongres sebagai upaya untuk melakukan kontrol terhadap pemerintahan dengan mengatakan "in framing a government which is to be administered by men over men ... you must first enable the government to control the governed; and in the next place oblige it to control itself." Lebih jauh Madison 
menyebutnya sebagai bagian dari checks and balances system dengan mengatakan ".... in all the subordinate distribution of power, where the constant aim is to divide and arrange the several offices in such a manner as that each may be a check on the other" (Madison et al., 2001: 269).

Menurut Mantel menyebutkan secara implisit, kekuasaan penyelidikan yang dimiliki Kongres bersumber pada tiga ketentuan yang terdapat dalam Konstitusi Amerika Serikat (2008: 327), yaitu:

1. Ketentuan pertama terdapat dalam Article I, Section 1, "All legislative powers herein granted shall be vested in a Congress ..." Mantel mengatakan, tanpa adanya kekuasaan penyelidikan, termasuk di dalamnya kekuasaan untuk memperoleh latar belakang data dan informasi yang tepat, maka Kongres tidak akan dapat menyusun legislasi yang efektif;

2. Ketentuan kedua terdapat dalam Article I, Section 2, Clause 5, which grants the House of Representatives the power to impeach, dan Article I, Section 3, Clause 6, which grants the Senate the power to try officials impeached by the House. Dua ketentuan dalam rangka impeachment tersebut adalah kewenangan untuk melakukan penyelidikan terhadap perilaku pejabat publik;

3. Ketentuan ketiga terdapat dalam Article I, Section 8, Clause 18 of the Constitution grants Congress the power to make "all laws which shall be necessary and proper for carrying into execution the foregoing powers ...." Ketentuan klausul "necessary and proper" (keperluan dan kelayakan) memungkinkan Kongres untuk menciptakan sarana dan alat dalam rangka melaksanakan tujuan badan legislatif. Karena itu, kekuasaan penyelidikan Kongres adalah hal yang inheren untuk memastikan penerapan hukum yang tepat.

Dari sini dapat diperoleh informasi bahwa penggunaan hak angket tidak selalu dalam rangka memintai pertanggungjawaban (impeachment), melainkan juga dalam rangka pembentukan undang-undang (legislasi), dan dalam rangka melakukan pengawasan yang efektif terhadap implementasi undang-undang.

Keempat, dari perspektif tujuan penggunaan hak angket. Dengan mempertimbangkan sejarah lahirnya hak angket dan perbandingannya dalam sistem pemerintahan, majelis hakim konstitusi melakukan konstruksi berkaitan dengan tujuan penggunaan hak angket. Kelompok hakim konstitusi yang mayoritas mengatakan hasil penggunaan hakangket tidak harus selaluberujung pada penggunaan hak menyatakan pendapat yang berujung pada rekomendasi/usulan penggantian pejabat yang melanggar undang-undang, melainkan dapat digunakan untuk merumuskan kebijakan perbaikan undang-undang dalam fungsi legislasi, perbaikan standard operational procedure, maupun kebijakan-kebijakan lainnya.

Kelompok hakim konstitusi yang dissenting opinion mengatakan hasil penyelidikan hak angket adalah sama-sama untuk pengawasan terhadap eksekutif, yang membedakannya, jika dalam sistem parlementer berujung pada jatuhnya pemerintahan, sementara dalam sistem presidensial tidak dapat berujung pada jatuhnya pemerintahan. Sampai dengan empat pertimbangan dalam merekonstruksi hak angket yang dipergunakan oleh kelompok hakim konstitusi yang mayoritas yang kemudian menjadi dasar keluarnya Putusan Nomor 36/ 
PUU-XV/2017 maupun hakim konstitusi yang menyatakan dissenting opinion, maka dapat dikatakan kedua kelompok tersebut memiliki cara pandang yang nyaris sama hanya beda dalam titik tekannya, sehingga saling melengkapi.

Apabila dilihat lebih jauh, tidak hanya pertimbangan dari aspek istilah, sejarah, perbandingan dalam sistem pemerintahan dan tujuan dari penggunaan hak angket, majelis hakim konstitusi khususnya yang mayoritas juga mempertimbangkan aspek sejarah penggunaan hak angket di Indonesia. Dalam pertimbangan Putusan Nomor 36/PUU-XV/2017 dikatakan bahwa hak angket di Indonesia telah diterima sebagai istilah dan praktik ketatanegaraan sejak lama, yaitu ketika diberlakukannya Konstitusi Republik Indonesia Serikat (RIS) 1949 dan UUDS 1950 yang menganut sistem pemerintahan parlementer. Pasal 121 Konstitusi RIS 1949 sama bunyinya dengan Pasal 70 UUDS 1950, yaitu: "Dewan Perwakilan Rakyat mempunyai hak menyelidiki (enquete)."

Adapun undang-undang organik mengenai hak angket diatur dalam Undang-Undang Nomor 6 Tahun 1954 tentang Penetapan Hak Angket Dewan Perwakilan Rakyat. Dengan demikian pengaturan hak angket mula-mula ditetapkan pada masa berlakunya sistem pemerintahan parlementer, namun dalam perkembangannya, setelah diberlakukannya kembali UUD NRI 1945 yang menganut sistem pemerintahan presidensial, eksistensi hak angket tetap dipertahankan. Demikian juga setelah terjadi perubahan UUD NRI 1945 (tahun 1999-2002), eksistensi hak angket semakin kuat karena diatur dalam Pasal 20A ayat (2) UUD NRI 1945, yaitu: “... Dewan Perwakilan Rakyat mempunyai hak interpelasi, hak angket, dan hak menyatakan pendapat.”
Dari perspektif sejarah pemberlakuan hak angket sebagaimana disebutkan dalam pertimbangan hakim konstitusi tersebut, serta dasar hukum hak angket yang saat ini masih berlaku (existing), maka semakin menegaskan bahwa kedudukan hak angket Dewan Perwakilan Rakyat dalam ketatanegaraan Indonesia adalah sangat kuat. Bahkan apabila dibandingkan dengan kekuasaan penyelidikan Kongres Amerika Serikat yang ternyata bersumber dari kekuasaan yang melekat (inherent) maupun yang tersirat (implied), maka hak angket Dewan Perwakilan Rakyat adalah kewenangan yang secara tegas disebutkan alias tersurat (expressis). Berdasarkan hal tersebut, maka tidak relevan lagi sebenarnya memperdebatkan apakah dalam ketatanegaraan yang menganut sistem presidensial seperti di Indonesia, badan perwakilannya dapat memiliki hak angket atau hak penyelidikan tersebut.

Hal yang kemudian perlu dicatat dalam hal kekuasaan penyelidikan yang dimiliki badan perwakilan sebagaimana Kongres di Amerika, bukan saja dalam rangka pengawasan dengan tujuan memintai pertanggungjawaban dalam prosedur impeachment, melainkan juga dalam rangka menjalankan kekuasaan pembuatan undang-undang (legislasi) sehingga dapat lebih efektif dalam upaya mencari latar belakang dan formulasi yang tepat terhadap suatu permasalahan dalam rangka pembentukan undang-undang. Selain itu juga dalam rangka pengawasan efektif terhadap jalannya undang-undang yang telah dibuat oleh legislatif.

Hal tersebut juga sejalan dengan pertimbangan Putusan Nomor 36/PUU-XV/2017 dengan mengatakan bahwa pemahaman terhadap hak angket tidak dapat dilepaskan dari fungsi pengawasan Dewan Perwakilan Rakyat, yakni pengawasan atas pelaksanaan undang-undang 
dan APBN. Oleh karena itu, penyelidikan yang dilakukan Dewan Perwakilan Rakyat dapat digunakan untuk memperoleh pandangan mengenai suatu hak dalam rangka pelaksanaan tugas menetapkan kebijakan, mungkin pula untuk mempersiapkan rancangan undang-undang inisiatif, atau memperoleh keterangan tentang suatu penyelewengan. Secara lebih tegas majelis hakim konstitusi menyimpulkan bahwa:

“... tidak selalu hasil penyelidikan Dewan Perwakilan Rakyat melalui penggunaan hak angket harus berujung pada penggunaan hak menyatakan pendapat, apalagi sematamata berupa rekomendasi/usulan pergantian terhadap pejabat tertentu yang terbukti melanggar undang-undang. Sebab sekali lagi, hak angket harus dimaknai sebagai instrumen pelaksanaan fungsi pengawasan Dewan Perwakilan Rakyat, sehinggatemuantemuan hak angket tersebut harus dapat dimaknai sebagai rekomendasi dan acuan mengikat bagi langkah-langkah evaluasi dan perbaikan di masa mendatang atas suatu hal yang menjadi objek penyelidikan."

Sampai dengan di sini, pertimbangan majelis hakim konstitusi dapat dikatakan secara tepat mengkonstruksikan hak angket sebagai fungsi pengawasan Dewan Perwakilan Rakyat yang tidak hanya terbatas pada bagian dari satu kesatuan pelaksanaan hak interpelasi dan hak menyatakan pendapat, melainkan lebih luas dari itu, dapat pula dalam rangka pembentukan undang-undang (legislasi) maupun kebijakan lainnya. Bahkan apabila merujuk pada pendapat Tambunan (1998: 158-159), ada empat jenis hak angket, yaitu hak angket dalam bidang keuangan (financial enquete); hak angket di bidang legislatif (legislative enquete); hak angket di bidang politik (political enquete); dan angket soal pemilihan umum (election enquete).

Berdasarkan praktik yang pernah terjadi, pada tahun 1950-an pernah dibentuk
Panitia Angket yang diketuai oleh Margono Djojohadikusumo dalam rangka menyelidiki untung-rugi mempertahankan devisen-regime berdasar Undang-Undang Pengawasan Devisen Tahun 1940 dan perubahan-perubahannya (Hantoro, 2004: 153; Madril, 2008).

Menurut Manan, hasil dari angket tersebut adalah untuk memperbarui undang-undang warisan Hindia Belanda, sehingga penggunaan hak angket tidak selalu dalam rangka pengawasan yang berujung pada pertanggungjawaban pejabat publik, melainkan dapat dimanfaatkan untuk menguji atau menyusun suatu kebijakan nasional yang dianggap mendasar, strategis, dan penting (Manan, 2018: 10).

Berdasarkan uraian tersebut, maka pengaturan hak angket yang terdapat dalam Undang-Undang Nomor 17 Tahun 2014 yang disatukan dalam bab mengenai pelaksanaan hak Dewan Perwakilan Rakyat bersama dengan hak interpelasi dan hak menyatakan pendapat semestinya perlu ditinjau ulang secara komprehensif. Perlu juga pengaturan penggunaan hak angket dalam kerangka pelaksanaan fungsi legislasi agar lebih efektif.

Hal yang menarik selanjutnya dalam Putusan Nomor 36/PUU-XV/2017 tersebut adalah bagaimana majelis hakim konstitusi mengkonstruksikan pertimbangan apakah Komisi Pemberantasan Korupsi dapat menjadi objek hak angket Dewan Perwakilan Rakyat atau tidak sesuai dengan permohonan yang diajukan.

Pertama, pertimbangan hakim konstitusi yang mayoritas. Dalam pertimbangan disebutkan bahwa dalam sistem ketatanegaraan Indonesia berdasarkan UUD NRI 1945 mengenal pembagian lembaga negara menjadi dua, yaitu: (1) lembaga negara yang bersifat utama (main state organs), 
di antaranya Majelis Permusyawaratan Rakyat, Dewan Perwakilan Rakyat, Dewan Perwakilan Daerah, Presiden-Wakil Presiden, Badan Pemeriksa Keuangan, Mahkamah Agung, dan Mahkamah Konstitusi; dan lembaga negara yang bersifat penunjang (auxiliary state organs) yaitu Komisi Yudisial.

Perkembangannya, lembaga negara yang bersifat penunjang tidak hanya lahir karena berdasarkan UUD NRI 1945, melainkan juga lahir karena perintah undang-undang di antaranya Komisi Pemilihan Umum, Komisi Pemberntasan Korupsi, dan lain-lain. Menurut hakim konstitusi mayoritas tersebut, dihadirkannya auxiliary state organ dalam ketatanegaraan Indonesia karena dorongan proses pencapaian tujuan negara yang semakin kompleks demi terwujudnya efektivitas dan efisiensi dalam pelaksanaan pelayanan publik maupun pencapaian penyelenggaraan negara.

Majelis hakim konstitusi yang mayoritas menggunakan pandangan Alder (1989) berkaitan dengan fungsi lembaga negara penunjang sebagai a quasi governmental world of appointed bodies, dan bersifat non-departemental agencies, single purpose authorities, dan mixed public private institutions. Terhadap fungsi yang dimiliki lembaga negara penunjang tersebut, maka ada dua pendapat, yaitu: (1) pendapat yang tetap mengelompokkan lembaga negara penunjang tetap dalam lingkup eksekutif; dan (2) pendapat yang menyatakan lembaga negara penunjang dalam kelompok kekuasaan baru yaitu kekuasaan keempat (the fourth branch of the government) sebagaimana dikatakan Menu \& Knapp (2002).

Dari pertimbangan tersebut, majelis hakim konstitusi yang mayoritas mengatakan keberadaan lembaga negara penunjang dibentuk dengan tetap berdasar pada fungsi lembaga negara utama yang menjalankan fungsi legislatif, eksekutif, dan yudikatif. Karena itu, majelis hakim konstitusi yang mayoritas menyebut Komisi Pemberantasan Korupsi sebagai lembaga yang berada di ranah eksekutif, karena melaksanakan fungsi-fungsi dalam domain eksekutif, yaitu penyelidikan, penyidikan, dan penuntutan, dalam rangka trigger mechanism terhadap lembaga Kepolisian dan Kejaksaan yang dianggap kurang dipercaya (public distrust) dalam pemberantasan tindak pidana korupsi.

Komisi Pemberantasan Korupsi juga bukan di ranah yudikatif karena bukan pengadilan yang mengadili dan memutus perkara. Komisi Pemberantasan Korupsi juga bukan badan legislatif, karena bukan organ pembentuk undang-undang. Selain itu, hakim konstitusi yang mayoritas juga mempertimbangkan Komisi Pemberantasan Korupsi adalah lembaga negara yang dalam melaksanakan tugas dan wewenangnya bersifat independen dan bebas dari pengaruh kekuasaan manapun. Menurut hakim konstitusi yang mayoritas, walaupun Komisi Pemberantasan Korupsi independen, Dewan Perwakilan Rakyat sebagai wakil rakyat berhak meminta pertanggungjawaban pelaksanaan tugas dan kewenangan Komisi Pemberantasan Korupsi, kecuali pelaksanaan tugas dan kewenangan yudisial.

Majelis hakim konstitusi yang mayoritas mengatakan bahwa tidaklah dapat dijadikan landasan untuk menyatakan hak angket Dewan Perwakilan Rakyat tidak meliputi Komisi Pemberantasan Korupsi sebagai lembaga independen, karena secara tekstual Komisi Pemberantasan Korupsi adalah organ atau lembaga yang termasuk eksekutif dan pelaksana undang-undang di bidang penegakan hukum khususnya dalam pemberantasan tindak pidana 
korupsi. Berdasarkan pertimbangan tersebut, majelis hakim konstitusi yang mayoritas menolak permohonan pengujian Pasal 79 Undang-Undang Nomor 17 Tahun 2014.

Kedua, pertimbangan yang dikemukakan oleh hakim konstitusi yang menyatakan dissenting opinion. Dalam pertimbangannya disebutkan bahwa dalam membaca penggunaan hak angket Dewan Perwakilan Rakyat yang terdapat dalam Undang-Undang Nomor 17 Tahun 2014, objek hak angket adalah pemerintah dalam arti pelaku kekuasaan eksekutif saja. Hal tersebut didasarkan pada pertimbangan sistem presidensial Indonesia, meletakkan Presiden sebagai pemegang kekuasaan pemerintahan yang sehari-hari menjadi penanggungjawab tertingginya.

Dalam perumusan Pasal 20A ayat (2) UUD NRI 1945, ihwal hak angket sebagai fungsi pengawasan Dewan Perwakilan Rakyat, secara eksplisit disebutkan penggunaannya dimaksudkan untuk mengawasi pemerintahan dalam arti eksekutif. Selanjutnya majelis hakim konstitusi yang dissenting opinion juga mempertimbangkan koherensi dalam membaca Pasal 79 Undang-Undang Nomor 17 Tahun 2014, di mana hak angket tidak dapat dilepaskan dari hak interpelasi dan hak menyatakan pendapat, sehingga berdasarkan penafsiran sistematis, tidak koheren apabila objek hak angket Dewan Perwakilan Rakyat dan juga hak-hak lainnya mencakup hal-hal yang berada di luar ruang kekuasan pemerintah (eksekutif).

Setelah mempertimbangkan penggunaan hak angket tersebut, yang menarik dari empat orang hakim konstitusi yang dissenting opinion, tiga orang di antaranya berpendapat bahwa organ negara yang disematkan status independen adalah berada di luar ketiga cabang kekuasaan dalam doktrin trias politika (eksekutif, legislatif, dan yudikatif). Dengan demikian Komisi Pemberantasan Korupsi sebagai lembaga independen adalah bukan bagian dari eksekutif. Karena itu, tiga orang hakim konstitusi yang menyatakan dissenting opinion, Komisi Pemberantasan Korupsi bukanlah objek hak angket Dewan Perwakilan Rakyat.

Satu orang hakim yang dissenting opinion memiliki pandangan bahwa Komisi Pemberantasan Korupsi termasuk dalam ranah kekuasaan pemerintahan (eksekutif) yang berciri independen. Walaupun demikian, Komisi Pemberantasan Korupsi tidak bertanggung jawab secara langsung kepada Presiden, melainkan bertanggung jawab kepada publik dan menyampaikan laporan secara terbuka dan berkala kepada Presiden, Dewan Perwakilan Rakyat, dan Badan Pemeriksa Keuangan sesuai dengan ketentuan undang-undang. Berdasarkan pertimbangan tersebut, satu orang hakim dissenting opinion Komisi Pemberantasan Korupsi bukan merupakan objek hak angket Dewan Perwakilan Rakyat (lihat tabel 2).

Perdebatan mengenai Komisi

Pemberantasan Korupsi dapat tidaknya menjadi objek hak angket Dewan Perwakilan Rakyat tersebut tentu menarik. Pertimbangan lima hakim konstitusi mayoritas yang menyebut Komisi Pemberantasan Korupsi sebagai bagian organ eksekutif yang independen namun tetap dapat menjadi objek hak angket masih menimbulkan pertanyaan, bagaimana status independensi Komisi Pemberantasan Korupsi, sehingga terlihat inkonsisten karena di satu sisi independen tetapi di sisi lain masih dapat dipengaruhi melalui mekanisme hak angket. 


\begin{tabular}{|c|c|c|}
\hline Isu & $\begin{array}{c}\text { Pertimbangan Hakim Konstitusi Mayoritas } \\
\text { yang Menjadi Dasar Putusan }\end{array}$ & $\begin{array}{c}\text { Pertimbangan Hakim Konstitusi Minoritas } \\
\text { yang Dissenting Opinion }\end{array}$ \\
\hline Pertimbangan & $\begin{array}{l}\text { Komisi Pemberantasan Korupsi sebagai } \\
\text { lembaga yang berada di ranah eksekutif, } \\
\text { karena melaksanakan fungsi-fungsi domain } \\
\text { eksekutif, yaitu penyelidikan, penyidikan, dan } \\
\text { penuntutan. Komisi Pemberantasan Korupsi } \\
\text { juga bukan di ranah yudikatif karena bukan } \\
\text { pengadilan yang mengadili dan memutus } \\
\text { perkara. Komisi Pemberantasan Korupsi } \\
\text { juga bukan lembaga legislatif, karena bukan } \\
\text { organ pembentuk undang-undang. Komisi } \\
\text { Pemberantasan Korupsi adalah lembaga } \\
\text { negara yang dalam melaksanakan tugas } \\
\text { dan wewenangnya bersifat independen dan } \\
\text { bebas dari pengaruh kekuasaan manapun, } \\
\text { namun demikian Dewan Perwakilan Rakyat } \\
\text { sebagai wakil rakyat berhak meminta } \\
\text { pertanggungjawaban pelaksanaan tugas dan } \\
\text { kewenangan Komisi Pemberantasan Korupsi, } \\
\text { kecuali pelaksanaan tugas dan kewenangan } \\
\text { yudisial. }\end{array}$ & $\begin{array}{l}\text { Dari empat hakim konstitusi yang dissenting } \\
\text { opinion, tiga di antaranya berpendapat bahwa } \\
\text { organ negara yang disematkan status independen } \\
\text { adalah berada di luar ketiga cabang kekuasaan } \\
\text { dalam doktrin trias politika (eksekutif, legislatif, } \\
\text { dan yudikatif), sehingga Komisi Pemberantasan } \\
\text { Korupsi sebagai lembaga independen adalah } \\
\text { bukan bagian dari eksekutif. Satu orang } \\
\text { hakim memiliki pandangan bahwa Komisi } \\
\text { Pemberantasan Korupsi termasuk dalam ranah } \\
\text { kekuasaan pemerintah (eksekutif) yang berciri } \\
\text { independen. Walaupun demikian, Komisi } \\
\text { Pemberantasan Korupsi tidak bertanggung } \\
\text { jawab secara langsung kepada Presiden, } \\
\text { melainkan bertanggung jawab kepada publik } \\
\text { dan menyampaikan laporan secara terbuka dan } \\
\text { berkala kepada Presiden, Dewan Perwakilan } \\
\text { Rakyat, dan Badan Pemeriksa Keuangan sesuai } \\
\text { dengan ketentuan undang-undang. }\end{array}$ \\
\hline Kesimpulan & $\begin{array}{l}\text { Komisi Pemberantasan Korupsi termasuk } \\
\text { objek hak angket Dewan Perwakilan Rakyat. }\end{array}$ & $\begin{array}{l}\text { Komisi Pemberantasan Korupsi bukan } \\
\text { merupakan objek hak angket Dewan Perwakilan } \\
\text { Rakyat. }\end{array}$ \\
\hline
\end{tabular}

Pendapat tiga hakim konstitusi yang dissenting opinion secara konsisten menyebut Komisi Pemberantasan Korupsi bukan sebagai organ eksekutif sehingga tidak dapat menjadi objek hak angket Dewan Perwakilan Rakyat. Sikap konsisten tersebut juga disebutkan oleh satu hakim konstitusi yang dissenting opinion yang menyebut Komisi Pemberantasan Korupsi sebagai organ eksekutif yang independen sehingga tidak dapat menjadi objek hak angket.

\section{B. Implikasi Putusan Nomor 36/PUU- XV/2017 Terhadap Objek Hak Angket Dewan Perwakilan Rakyat dalam Ketatanegaraan Indonesia}

Sebagaimana telah disebutkan, bahwa Putusan Nomor 36/PUU-XV/2017 menyatakan bahwa Komisi Pemberantasan Korupsi adalah objek hak angket Dewan Perwakilan
Rakyat dengan pertimbangan bahwa Komisi Pemberantasan Korupsi termasuk lembaga negara penunjang dalam ranah eksekutif. Walaupun memiliki independensi yang dijamin oleh undang-undang, namun penggunaan hak angket Dewan Perwakilan Rakyat tetap dapat diberikan kepada Komisi Pemberantasan Korupsi.

Implikasi dari putusan tersebut, dapat dikelompokkan dalam dua hal, yaitu: pertama, implikasi yang bermuatan positif, yaitu penegasan dimilikinya hak angket Dewan Perwakilan Rakyat dalam ketatanegaran Indonesia. Mengapa disebut bermuatan positif, karena dengan adanya putusan tersebut, khususnya dengan melihat pertimbangan majelis hakim (baik yang mayoritas maupun yang menyatakan dissenting opinion) telah mengkonstruksi hak angket sebagai fungsi pengawasan yang melekat pada Dewan Perwakilan Rakyat tanpa 
harus memperdebatkannya dengan sistem pemerintahan. Baik dalam sistem parlementer maupun sistem presidensial, hak angket atau hak penyelidikan Dewan Perwakilan Rakyat adalah suatu kelaziman.

Hak angket dikonstruksikan tidak selalu dipergunakan untuk menyelidiki persoalan yang berujung pada upaya impeachment terhadap pejabat publik, melainkan juga dapat dipergunakan untuk penyelidikan kebijakan penting yang hasilnya adalah perlunya pembentukan kebijakan tertentu dalam bidang legislasi. Dengan demikian, Dewan Perwakilan Rakyat dapat saja membentuk panitia angket dalam rangka penyelidikan kebijakan tertentu dalam hal pembentukan undang-undang. Ini dapat menjadi salah satu terobosan untuk meningkatkan efektivitas pembentukan undang-undang di Dewan Perwakilan Rakyat yang selama ini banyak terkendala dari aspek waktu pembahasan yang sering ditunda-tunda. Dengan membentuk panitia angket dalam rangka penyelidikan kebijakan dalam bidang perundang-undangan, maka anggota Dewan Perwakilan Rakyat yang tergabung di dalamnya akan lebih fokus karena dibatasi waktu pengerjaannya. Misalnya saja dalam pembentukan undang-undang yang krusial, mendasar dan penting bagi rakyat, yaitu perubahan KUHP, KUHAP, dan lain-lain dapat diawali dengan pembentukan panitia angket.

Kedua, implikasi yang bermuatan negatif yaitu adanya kemungkinan penggunaan hak angket Dewan Perwakilan Rakyat yang eksesif tanpa memperhatikan batasan-batasan yang ada. Hal tersebut dikarenakan majelis hakim konstitusi tidak melakukan konstruksi pembatasan terhadap penggunaan hak angket yang dilakukan oleh Dewan Perwakilan Rakyat, karena terlalu berfokus pada persoalan apakah
Komisi Pemberantasan Korupsi dapat dijadikan objek hak angket atau tidak.

Majelis hakim konstitusi hanya menyebut "kecuali pelaksanaan tugas dan kewenangan yudisial," yang tidak dielaborasi lebih lanjut. Misal dalam kasus konkret alasan Dewan Perwakilan Rakyat mengadakan angket adalah ketidakmauan Komisi Pemberantasan Korupsi membuka rekaman pemeriksaan MSH, padahal secara jelas Komisi Pemberantasan Korupsi mengatakan hal tersebut merupakan bagian dari proses penegakan hukum pro justicia. Akibat tidak adanya elaborasi lebih lanjut terhadap bagaimana membatasi hak angket tersebut, maka penggunaan hak angket akan sangat mungkin dilakukan secara eksesif yang dapat berupa lembaga negara maupun materi yang menjadi objek hak angket.

Dalam konteks kelembagaan negara, penggunaan hak angket yang eksesif dapat merambah lembaga negara yang bukan bagian dari eksekutif. Misalnya saja Mahkamah Agung dan Mahkamah Konstitusi sebagai pemegang kekuasaan yudikatif, yang menurut UUD NRI 1945 adalah kekuasaan kehakiman yang merdeka. Hal tersebut misalnya disebutkan oleh Yusril Ihza Mahendra saat memberikan keterangan kepada Panitia Angket dengan mengatakan bahwa semua lembaga dapat menjadi objek hak angket Dewan Perwakilan Rakyat, tidak hanya Komisi Pemberantasan Korupsi, karena hak angket menjadi semacam kontrol terhadap lembaga-lembaga negara termasuk di dalamnya Mahkamah Agung, dengan batas-batas tertentu. Batasannya adalah angket tidak dapat digunakan jika alasannya terkait dengan materi perkara yang ditangani Mahkamah Agung, tetapi dapat digunakan jika ada dugaan suap dalam urusan suatu perkara di Mahkamah Agung (dalam Novianti, 2018: 4). 
Pandangan hak angket Dewan Perwakilan Rakyat yang dapat menjadikan Mahkamah Agung sebagai objek hak angket tersebut tentu masih dapat diperdebatkan. Apalagi jika dikaitkan dengan sifat kekuasaan kehakiman yang merdeka. Bukankah salah satu jaminan kekuasaan yang merdeka adalah adanya kemerdekaan secara kelembagaan sebagaimana disebut dalam Bangalore Principle: "Judicial independence is a prerequisite to the rule of law and a fundamental guarantee of a fair trial. A judge shall therefore uphold and exemplify judicial independence in both its individual and institutional aspects." Independensi kekuasaan kehakiman tidak hanya terletak pada independensi hakim secara individu melainkan juga secara kelembagaan (UNODC, 2007: 39-40). Jika kemudian Mahkamah Agung atau bahkan Mahkamah Konstitusi dapat dijadikan objek hak angket secara kelembagaan, maka bagaimana status kemerdekaan kekuasaan kehakiman. Persoalan ini yang harus diteliti lebih lanjut.

Selain dapat menimbulkan pelaksanaan hak angket yang eksesif secara kelembagaan, hak angket yang eksesif juga dapat berkaitan dengan materi yang dijadikan objek hak angket. Dalam perkara hak angket terhadap Komisi Pemberantasan Korupsi misalnya, adalah dikarenakan menolak dan tidak mau membuka rekaman pemeriksaan MSH di Komisi III Dewan Perwakilan Rakyat. Melalui panitia angket, Dewan Perwakilan Rakyat berharap dapat memaksa Komisi Pemberantasan Korupsi untuk dapat membuka rekaman penyidikan tersebut karena kekuatan hak angket adalah dapat memaksa berbagai macam pihak untuk hadir dalam persidangan panitia angket.

\section{Komisi Pemberantasan Korupsi} menjelaskan rekaman penyidikan MSH adalah dalam konteks penegakan hukum pro justicia. Dengan demikian, rekaman tersebut hanya dapat dibuka dalam rangka penegakan hukum pro justicia juga yaitu di pengadilan, bukan di lembaga lainnya, apalagi Dewan Perwakilan Rakyat yang merepresentasikan lembaga politik, sehingga akan sangat mungkin terjadi politisasi kasus hukum. Contoh inilah yang menunjukkan bahwa materi hak angket Komisi Pemberantasan Korupsi sangat mungkin eksesif, meluas, dan menabrak ketentuan hukum lainnya.

Apabila merujuk pada prasyarat yang ada dalam ketentuan Pasal 79 bahwa hak angket dipergunakan untuk hal yang sifatnya penting, strategis, dan berdampak luas terhadap kehidupan bermasyarakat, berbangsa, dan bernegara, maka apakah penolakan Komisi Pemberantasan Korupsi untuk menyerahkan atau membuka rekaman tersebut termasuk ke dalam sesuatu hal yang penting dan strategis yang akan berdampak pada peri kehidupan bermasyarakat, berbangsa, dan bernegara.

Manan mengatakan, bukankah merupakan asas alias prinsip bahwa pada tingkat penyelidikan dan penyidikan pro justicia harus dirahasiakan terhadap publik untuk melindungi subjek yang diselidiki atau disidik, orang-orang lain yang disebut dalam penyelidikan dan penyidikan, termasukjuga kepentingan penyelidik dan penyidik agar terhindar dari berbagai pendapat atau persepsi publik yang akan mempersulit menemukan bukti awal yang cukup untuk menetapkan suatu persangkaan (Manan, 2018: 18-19).

Menurut Charity, penggunaan hak angket Dewan Perwakilan Rakyat terhadap Komisi Pemberantasan Korupsi hanya untuk membuka rekaman hasil pemeriksaan penyidikan MSH adalah tidak tepat dan salah sasaran karena 
Komisi Pemberantasan Korupsi sedang menjalankan kewenangannya sebagai penegak hukum (Charity, 2017: 253).

Bahkan lebih jauh berkaitan dengan alasan dipergunakannya hak angket terhadap Komisi Pemberantasan Korupsi yakni: (1) adanya temuan Badan Pemeriksa Keuangan tentang penyimpangan penyelenggaraan keuangan; (2) terkait tata kelola dokumentasi dalam proses hukum penindakan dugaan korupsi, dengan adanya kasus pembocoran dokumen dalam proses hukum tersebut seperti berita acara pemeriksaan, sprindik, dan surat cekal; (3) adanya dugaan perpecahan internal dan ketidakharmonisan di tubuh Komisi Pemberantasan Korupsi, bahkan sikap insubkoordinasi dari kalangan internal dengan pimpinannya komisioner Komisi Pemberantasan Korupsi.

Apakah ketiga alasan tersebut dapat dikatakan bersifat penting, strategis, dan berdampak luas terhadap kehidupan bermasyarakat, berbangsa, dan bernegara? Dalam hal temuan Badan Pemeriksa Keuangan misalnya, mengapa temuan pada lembaga atau instansi lainnya bahkan ada yang menyatakan “adanya potensi kerugian negara” tidak semuanya menjadi objek hak angket oleh Dewan Perwakilan Rakyat. Bukankah dalam UUD NRI 1945 Pasal $23 \mathrm{E}$ ayat (2) dikatakan "hasil pemeriksaaan diserahkan kepada DPR dan DPRD”, dan ayat (3) dikatakan "hasil pemeriksaan ... ditindaklanjuti oleh lembaga perwakilan dan/atau badan sesuai dengan undang-undang” (Manan, 2018: 18).

Persoalan adanya implikasi penggunaan hak angket yang eksesif tersebut dikarenakan majelis hakim konstitusi tidak melakukan pertimbangan perlunya pembatasan-pembatasan tertentu dalam penggunaan hak angket. Padahal penggunaan hak angket yang eksesif dan berlebihan tanpa batasan akan dapat menciptakan penyalahgunaan kekuasaan sehingga keinginan menghadirkan hak angket sebagai fungsi pengawasan Dewan Perwakilan Rakyat dalam kerangka checks and balances justru sulit tercapai. Padahal fungsi pengawasan badan perwakilan merupakan sarana esensial sistem checks and balances dalam demokrasi (IPU, 2017: 1). Apalagi dari pengalaman praktik penggunaan hak angket di Indonesia lebih banyak memperlihatkan kepentingan politik semata, yang tidak disertai solusi dan efektivitas terhadap hasil penyelidikan (Ratu, 2017: 224; Subardjo, 2016: 81).

Di Amerika Serikat, pembatasan terhadap penggunaan Congressional Investigations juga cukup sulit dirumuskan (Millikan, 1967: 659). Namun demikian menurut Mantel, Congress investigative power is not without limits (hak penyelidikan Kongres bukan tanpa batas) yang didasarkan pada Putusan Mahkamah Agung Amerika Serikat dalam perkara Watkins vs. United States, misalnya mengatakan:

"There is no general authority to expose the private affairs of individuals without justification in terms of the functions of the Congress. ... Nor is the Congress a law enforcement or trial agency. These are functions of the executive and judicial departments of government. No inquiry is an end in itself; it must be related to, and in furtherance of, a legitimate task of the Congress." (Mantel, 2008: 328).

Dengan demikian, kekuasaan penyelidikan Kongres dibatasi untuk tidak mengekspos urusan pribadi individu, penegakan hukum, ataupun hal lainnya yang bukan merupakan kewenangan ataupun tidak memiliki relasi secara langsung terhadap persoalan yang sedang diselidiki. Urusan pribadi merupakan urusan privat yang dijamin oleh Konstitusi Amerika, sehingga penyelidikan 
Kongres tidak dapat melakukan terhadap hal tersebut (Garcia et al., 2017: 105). Selain itu, bagi Millikan para anggota panitia investigasi kongres harus mengembangkan self-restraint (pengekangan diri) untuk tidak melampaui batasbatas hukum dalam penggunaan Congressional Investigations tersebut (Millikan, 1967: 660).

Secara umum menurut Reinstein, pembatasan kekuasaan Kongres di Amerika, baik melalui pengadilan maupun oleh para akademisi melaluipengembanganteori-teori,perludilakukan karena ketidaksempurnaan pembentukan sebuah konstitusi (Reinstein, 2016: 13-22, 77-81). Itu artinya ada kesadaran bahwa konstitusi yang tertulis tidak akan selalu sempurna dan dapat menjawab segala persoalan yang berkembang, khususnya dalam menjalankan tugas badan perwakilan. Dari contoh pembatasan penggunaan hak angket di Amerika Serikat tersebut, maka pembatasan penggunaan hak angket di Indonesia semestinya juga harus dilakukan. Karena itu masih perlu diteliti secara lebih lanjut terhadap apa saja yang dapat dijadikan pembatasan, apakah cukup hak privasi orang, lembaga yang merdeka atau independen atau terhadap substansi yang akan dijadikan objek hak angket.

Berdasarkan uraian yang telah disampaikan, dalam kerangka membuat hak angket yang efektif, tidak hanya dalam rangka pengawasan yang berujung pada penjatuhan sanksi bagi pejabat publik, melainkan juga dalam rangka pengawasan pelaksanaan undangundang yang berujung pada perubahan undangundang melalui program legislasi, serta dalam rangka memberikan pembatasan terhadap penggunaan hak angket agar tidak eksesif, maka diperlukan pengaturan yang lebih mendetil dalam pelaksanaan hak angket yang diatur dalam Undang-Undang Nomor 17 Tahun 2014.
Hal ini sejalan juga dengan pendapat Fitria mengenai perlunya penguatan fungsi pengawasan Dewan Perwakilan Rakyat melalui perubahan Undang-Undang Nomor 10 Tahun 1954 tentang Hak Angket karena telah usang (Fitria, 2014: 88), maupun pendapat Hantoro yang menyebut pengaturan hak angket dalam Undang-Undang Nomor 17 Tahun 2014 belum komprehensif (Hantoro, 2017: 178).

\section{KESIMPULAN}

Berdasarkan hasil pembahasan, maka dapat disimpulkan:

1. Putusan Nomor 36/PUU-XV/2017 telah mengkonstruksikan hak angket tidak hanya dalam kerangka pengawasan yang hasilnya berujung pada penjatuhan sanksi bagi pejabat publik yang melanggar undangundang, melainkan juga pengawasan pelaksanaan undang-undang yang hasilnya berupa perubahan kebijakan dalam rangka perubahan undang-undang (legislasi) maupun kebijakan lainnya. Putusan tersebut juga mengkonstruksi Komisi Pemberantasan Korupsi sebagai lembaga negara penunjang dalam ranah eksekutif yang independen, namun tetap dapat menjadi objek hak angket Dewan Perwakilan Rakyat.

2. Putusan tersebut secara positif berimplikasi dapat digunakannya hak angket dalam rangka perubahan undang-undang sehingga dapat meningkatkan efektivitas legislasi, namun secara negatif berimplikasi dapat digunakannya hak angket secara eksesif terhadap kelembagaan yang dijamin independensinya dan terhadap objek yang seharusnya tidak dapat diselidiki karena 
dilindungi hukum, misalnya hak privasi dan penegakan hukum. Implikasi eksesif tersebut disebabkan putusan tersebut tidak memberikan batasan terhadap penggunaan hak angket Dewan Perwakilan Rakyat.

\section{DAFTAR ACUAN}

Alder, J. (1989). Constitutional \& administrative law. London: MacMillan Press LTD.

Asshiddiqie, J. (2006). Pengantar ilmu hukum tata negara jilid II. Jakarta: Konstitusi Press.

Charity, M.L. (2017, September). Implikasi hak angket Dewan Perwakilan Rakyat Republik Indonesia terhadap Komisi Pemberantasan Korupsi. Jurnal Legislasi Indonesia, 14(03), 245-254.

Ehrmann, H.W. (1943). The duty of disclosure in parliamentary investigation: A comparative study. The University of Chicago Law Review, 11(2), 117-153.

Fitria. (2014). Penguatan fungsi pengawasan DPR melalui perubahan Undang-Undang Nomor 10 Tahun 1954 tentang Hak Angket. Jurnal Cita Hukum, I(1), 79-88.

Garcia, M.J., et al. (2017). The constitution of the United States of America, analysis \& interpretation. Legislative Department. Washington: U.S. Government Publishing Office.

Hantoro, N.M. (2004). Pelaksanaan fungsi pengawasan Dewan Perwakilan Rakyat melalui hak angket dalam Sistem Ketatanegaraan Republik Indonesia. Tesis. Jakarta: Universitas Indonesia.

(2017). Urgensi pembentukan Undang-
Undang Hak Angket DPR RI. Negara Hukum. 8(2), 177-194.

Harpine, A.C. (1956). Congressional investigating power, judicial interpretation of the scope of inquiry. American University Law Review, $5(2), 64-81$.

Indrayana, D. (2017). KPK bukan eksekutif, angket KPK inskonstitusional. Diakses dari https:// kumpa-ran.com/@kumparannews/kpkbukaneksekutif-angket-kpk-inkonstitusional)

Inter-Parliamentary Union (IPU). (2017). Global parliementary report 2017, parliamentary oversight: Parliament's power to hold government to account. IPU-UNDP.

Istanto, F.S. (2007). Penelitian hukum. Yogyakarta: CV. Ganda.

Kaiser. F.M. (1988). Congressional oversight of the presidency. The Annals of the American Academy, 499(1), 75-89.

Madison, J., Hamilton, A., \& Jay, J. (2001). The federalist. Indiana: Liberty Fund.

Madril, O. (2008). Angket BBM \& pemakzulan presiden. Jawa Pos.

Manan, B. (2003). Teori \& politik konsonstitusi. Yogyakarta: FH UII Press.

(2006). Lembaga kepresidenan. Yogyakarta: FH UII Press. . (2018). Hak angket sebagai kekuasaan pengawasan DPR. Jurnal Varia Peradilan, XXXIII(387), 6-23.

Mantel, M. (2008). Conggresional Investigation: A Bibliography. Law Library Journal, 100(2), 323-361.

Marzuki, P.M. (2005). Penelitian hukum. Jakarta: Kencana Prenada Media Group. 
Menu, YU., \& Knapp, K. (2002). Government \& politic in western Europe: Britain, France, Italy, Germany. $3^{\text {rd }}$ Edition. Oxford: Oxford University Press.

Mill, J.S. (1861). Considerations on representative government. London: Savill and Edwards Printers.

Millikan, K.B. (1967). Limitation on the power of congressional investigations. William \& Mary Law Review. 8(4), 630-660.

Montesquieu, B. (2001). The spirit of laws. Trans. Thomas Nugent. Ontario: Batoche Books.

Naswar. (2012). Hak angket dalam konstelasi ketatanegaraan Indonesia. Jurnal Konstitusi. I(1), 1-13.

Netherlands Government. (2012). The constitution of the Kingdom fo Netherlands. Diakses dari (https://www.government.nl/documents/ regulations/2012/10/18/theconstitution-of-thekingdom-of-the-ne-therlands-2008).

Novianti. (2018). Implikasi putusan MK atas penggunaan hak angket DPR terhadap KPK. Info Singkat DPR. X(4), 1-6.

Ratu. S.S.L. (2017, Agustus). Hakikat hak angket anggota Dewan Perwakilan Rakyat dalam sistem ketatanegaraan Republik Indonesia. Mimbar Keadilan Jurnal Ilmu Hukum. 13(26), 209-228.

Reinstein. R.J. (2016). The limits of congressional power. Temple Law Review, (89)1, 1-94.

Senat Amerika. (2018). History of investigation. Diakses dari (https: //www.senate.gov/ artandhistory/history/common/briefing/ Investigations.html).

Srem-Sai. (2014). Paliamentary oversight in ghanaA brief review. Fridrich Ebert-Stiftung Ghana.
Subardjo. (2016, Februari). Penggunaan hak angket oleh DPR RI dalam mengawasi kebijakan pemerintah. Jurnal Ilmu Hukum Novelty, 7(1), Februari 2016, 71-82.

Supranto, J. (2003). Metode penelitian hukum \& statistik. Cetakan I. Jakarta: Penerbit Rineka Cipta.

Susanto, M. (2013). Hak budget parlemen di Indonesia. Jakarta: Sinar Grafika.

Tambunan, A.S.S. (1998). Fungsi Dewan Perwakilan Rakyat Republik Indoensia menurut UUD NRI 1945, suatu studi analisis mengenai pengaturannya tahun 1966-1997. Jakarta: Sekolah Tinggi Hukum Militer.

United Nations Office on Drugs and Crime (UNODC). (2007). Commentary on the Bangalore Principles of Judicial Conduct.

Webster, M. (2018). Merriam Webster Dictionary, Inquiry. Diakses dari (http://www.merriamwebster.com/dictio-nary/inquiry).

Yamamoto, H. (2007). Tools for parliamentary oversight a comparative study of 88 National parliaments. Geneva: Inter-Parliamentary Union. 